\title{
The Handbook of Globalisation: introduction and overview
}

Since the 1980s it had been fashionable to suggest that there was little that individual countries could do in the face of global economic forces, and any attempt to pursue independent policies would be doomed to failure. 'Even China', it was often said, was embracing the global free market. The idea that developing countries, such as India, could promote their own developmental interests by sheltering behind exchange controls or national planning had been swept away along with the Berlin Wall. In the globalised economy of the twenty-first century, it was argued, national governments had to go with the flow of global markets.

As the 2008 international financial crisis was breaking, the global strategy firm Oxford Analytica held one of its usual daily analysis sessions, but open to those attending its annual conference. The chair briefly summarised the unfolding global crisis, and then went round the table asking the various national experts to report. Despite the consensus referred to above, the reports did not paint a picture of a uniform globalised market to which each country related in the same way. The US and UK had been referred to in the opening statement, being very much at the centre of whatever it was that had caused the worst economic crisis since the 1930s. But when the expert on Brazil was called, he reported that the socialist President Lula had kept its financial sector rather independent of the global markets. Next India, and here too it was reported that it actually hadn't opened itself up to the global market quite as much as might have been thought. Then China, where, it was reported, the Communist Party had maintained rather a firm grip.

Of course, no one can escape a world economic crisis, and Brazil, India and China suffered along with the rest. But it was clear that those countries had developed a rather different relation to the global market economy than had the US and the UK. Brazil, India and China had not caused the crisis, and to some extent, at least, their own economic strategies and policies did enable them to survive the global recession in better shape than if they had fully joined in the orgy of free-market globalisation that the UK and US had been championing through the 1980s and 1990s.

So, the continued globalisation of economic activities is certainly of major significance for the prosperity - or otherwise - of the world's population; it has been accompanied by major policy debates and developments; and this 'globalisation' has been the subject of wide-ranging cross-disciplinary academic research for the past several years - some would say for the past several decades, a point discussed below. But the resulting academic debates are far from being resolved. In this, they reflect the continued policy debate and action, and the continuously changing contours of the globalisation process itself.

The purpose of the current volume is to bring together the key strands of this wideranging research agenda, and to report the latest state of play in the resulting academic debates. This literature is one that I have been involved in myself with various co-authors 
from a series of research projects. However, rather than include anything from these projects, or with my co-authors, within the body of this volume, I have instead referred liberally to various of these contributions within this introductory chapter, in which I also give an overview of the subsequent 28 chapters. All the 'classic' articles on globalisation from the literature are reproduced - along with many contemporary contributions (including my own) - in a major three-volume reader, Michie (ed.)(2017). ${ }^{1}$

\section{PART I: GLOBALISATION IN QUESTION?}

First is the question of how radical a break the current state of globalisation is from previous developments. The title of this first part of the book is taken from Hirst and Thompson (1996), who are sceptical of such claims. Chapter 1 of the current volume is reproduced from the previous edition, which itself was taken from the first edition since Paul Hirst sadly died before the second edition was commissioned; in that chapter, Hirst and Thompson had brought their arguments up to date from their 1996 book for the 2003 first edition of this volume, continuing though to question how unprecedented the globalisation developments of the 1990s really had been. In Chapter 2 Grahame Thompson challenges the notion that the 2008 financial crisis was global in scope. Rather, he argues, the international financial system is quite differentiated, even though it is, of course, characterised by contagion, to which he argues the best regulatory response is to develop what he describes as 'distributed preparedness for resilience', rather than top-down global rules that would rely on the same institutions of global economic governance that have failed us in the past.

Such scepticism is challenged by Jonathan Perraton in Chapter 3, who argues that globalisation is a process and so cannot be dismissed simply because it has not arrived at some pre-imagined 'state'. The question remains, however, of just how different the current globalisation process is from previous globalisation processes. Scepticism about this had been expressed by other authors before Hirst and Thompson, including the late Andrew Glyn, who in the previous edition had reported the latest state of play with his co-author Bob Sutcliffe, arguing that globalisation is widely misinterpreted, and that in particular its quantitative extent and novelty are exaggerated. Their chapter, Chapter 4, criticises the use of inappropriate statistical measures, conclusions drawn from little data and the failure to make historical comparisons, or to see counter-globalisation tendencies and limits to globalisation. The best measures suggest that globalisation is neither so new nor so great as is often supposed. The political implications of this argument are then briefly explored. ${ }^{2}$

Similarly, Costello et al. (1989) had argued that these globalisation trends 'have been with us for some time, and they need to be seen in historical context' (p. 38), and in particular need to be seen for what they are, namely an attempt to reconstruct the conditions for profitable growth internationally. As to whether the resulting globalisation would prevent national governments from pursuing any alternative paths, they argue (p. 55) that:

National economic management is only an anachronism if it is seen as operating in an international vacuum. Instead, the nation state should be recognized for what it is: the single most powerful mechanism of legal and organizational powers for economic intervention. 
As for whether such intervention is necessary, Michie (1995, p.xx) argues that:

The global economy can be imagined to be a self-equilibrating mechanism of the textbook variety, or it can be recognized as subject to processes of cumulative causation whereby if one or more countries fall behind the pack, there may be dangers of them falling further behind rather than enjoying an automatic ticket back to the equilibrium solution path. These two alternative, conflicting views of real world economic processes have very different implications regarding institutional needs and arrangements.

There are, then, two interrelated issues. First, how radically different are current processes from previous ones? And second, what are the policy implications? Michie (1996, p. 124) argued that of the variety on offer, the following description of the globalisation of economic activity is apposite:

\begin{abstract}
All old-established national industries have been destroyed or are daily being destroyed. They are dislodged by new industries, whose introduction becomes a life and death question for all nations, by industries that no longer work up indigenous raw material, but raw material drawn from the remotest zones; industries whose products are consumed, not only at home, but in every quarter of the globe. In place of the old wants, satisfied by the productions of the country, we find new wants, requiring for their satisfaction the products of distant lands. We have universal interdependence of nations. And as in material, so also in intellectual production.
\end{abstract}

This characterisation of globalisation processes was written more than 170 years ago. ${ }^{3}$ Likewise, the difficulties faced by national governments attempting to pursue policies in the face of globalisation have been discussed in detail for decades, and the actual difficulties have been faced up to and tackled, with varying degrees of both commitment and success, for decades as well:

The real question, then, is not whether it is best to act at the national or international level; it is how best to secure international action. For all to remain frozen until such time as everyone else moves is inadequate, however eloquent the calls for movement being made might be. Action at the local, regional, national or bloc level, far from being a utopian alternative to the real international stage, might in reality prove a prerequisite to cooperation. (Michie, 1996, p. 125)

\title{
PART II: ANALYSING THE GLOBAL ECONOMY
}

Globalisation is sometimes interpreted or presented as resulting from technological innovation, and certainly such innovation has fuelled globalisation processes. Likewise there have no doubt been demand-pull pressures from globalisation on new technologies, hastening their advent, adoption, diffusion and development. Jeremy Howells has been analysing such processes for many years, and he opens Part II in Chapter 5 by considering 'systems of innovation' within a global economy, both as a theoretical construct and as influencing how successfully economies can adapt and perform within an ever-changing global economic environment.

In Chapter 6, Gary Dymski reviews recent historical experience with international debt crises, with an emphasis on how economists have answered two core questions about these episodes - namely, why do they occur, and what should be done about them? He concludes that: 
Mainstream economists, then, view occurrences of international debt crisis as being attributable to flaws in, interference with, or poor supervision of, credit-market mechanisms. They represent disturbances to an otherwise achievable set of efficient-market outcomes (Crotty and Dymski, 2001), and thus create opportunities for regulatory fine-tuning. Non-mainstream economists see crises as confirmation that destabilizing impulses have not yet been adequately controlled, and/or as manifestations of power imbalances within nations or among them; so addressing the causes of financial crises requires, inter alia, addressing these imbalances.

Policy responses to the severe episodes of international debt crisis encompassed here have generally conformed to the mainstream economists' perspective: markets should be well-regulated, but otherwise left free to evolve; nation-states that fail to meet cross-border loan obligations should face the budgetary and growth-rate consequences; and the dual crisis that followed hard on the heels of the establishment of securitization-based, risk-hedged loan markets can be attributed to remediable mistakes in bank regulatory design. An assessment based on the idea that financial markets are inherently unstable and mirror social and political power imbalances would reach a very different conclusion: the recurrent bailouts of the banks that have precipitated these crises, without addressing the structural macroeconomic conditions that underly them, will only make future crises more likely. Until this view gains more currency, the costs of these crises will continue to fall most heavily on the most vulnerable nations and people. Whether this path is sustainable remains an open question.

The inequality to which Dymski refers is then analysed, in Chapter 7, by José Gabriel Palma, who examines the main stylised facts of the current broad spectrum of worldwide inequality and proposes new ways of looking at it - why do highly unequal middle-income countries (such as those in Latin America) tend to show the advanced ones the shape of things to come?

\section{PART III: TRANSNATIONAL CORPORATIONS}

Part III analyses the role of transnational corporations within the global economy. Grazia Ietto-Gillies in Chapter 8 provides a comprehensive overview of the role played within the current globalisation processes by transnational corporations. She argues that the dominant drivers of globalisation are first, technological innovation in the field of communication and information together with advances in the field of transportation, and second, organisational innovation and in particular the organisation of production across countries.

Gerry Epstein in Chapter 9 also provides data on the role of transnational corporations, and discusses the effect that the operation of transnational corporations has on the economy, and on specific economies that experience either outward or inward investment:

Despite the fact that there has been a great deal of research during the last several decades on MNCs [multinational corporations], there is no consensus on their effects. Still, the evidence that does exist suggests the following: though FDI [foreign direct investment] can have positive impacts on home and host countries, the likelihood that these positive effects will materialise and be widely shared is greatly diminished by the 'neo-liberal' policy framework that is dominant in much of the world today. I conclude that what is needed instead of more deregulation and 'free' capital mobility, is a more democratic framework of multinational investment regulation to help countries and their citizens reap the benefits that can be associated with international investment. If this were done properly, the tensions that arise between the interests of southern and northern workers might be significantly reduced. 
In Chapter 10, Elissa Braunstein reviews the literature dealing with gender and foreign direct investment (FDI). This literature covers a variety of topics, such as how women's roles outside the formal market sector can impact upon the profitability of multinational investment. The chapter focuses in particular on the implications of such work for a country's overall development strategy; for any government that is seeking to gain the maximum benefit from such inward investment, understanding the role of gender is key.

\section{PART IV: LABOUR STANDARDS}

In its first decade of operation, the International Labour Organization (ILO) adopted a convention on minimum wages - Convention 26 'Concerning the Creation of Minimum Wage-Fixing Machinery', 1928. Its concern was to ensure that global trade was not based on cheap labour. In Chapter 11, Peter Brosnan discusses the operation of minimum wage legislation within the context of globalisation - which makes the enforcement of such legislation more difficult but also, perhaps, more necessary.

The impact of this sort of labour standards legislation is discussed by Ajit Singh and Ann Zammit in Chapter 12 within the context of economic development more generally. They point to various difficulties, such as the limited proportion of the population for whom such legislation might actually impact, through to the more general problem that if such legislation hampers economic development, the losers in the long run may include those whom such legislation sets out to protect.

These various factors and arguments are considered and discussed by James Heintz in Chapter 13. He evaluates the danger of negative consequences, and discusses, within this context, current developments in implementation strategies, concluding that:

Regardless of the implementation strategy, the limitations of any scheme along these lines to introduce global labor standards should be explicitly recognized. Most significantly, only a subset of the world's workforce would receive any benefits, since the standards are aimed at workers who produce goods for export. Workers producing non-traded goods and services would not be directly affected by interventions such as a standardized code of conduct or a social clause. In these cases, the ongoing mission of the ILO to encourage states to implement and enforce better domestic standards remains invaluable. Furthermore, adopting expansionary macroeconomic policies could be more strategic for improving the well-being of all workers than a targeted set of labor standards. A coordinated approach involving a range of interventions both macroeconomic and in terms of international regulation - would also reduce the tensions between better standards and job creation.

Despite the limitations of global labor standards, the potential that such interventions have for improving the working lives of a significant number of people should not be underestimated. Furthermore, the possible impact of such a system extends well beyond the benefits generated by its core policies. The development of an appropriate regulatory scheme for enforcing basic standards of decency could serve as a model for governing multinational economic activities more generally. Because of these possible contributions, striving to create an effective framework for global labor standards represents an important policy goal in this era of the new international division of labor. 


\section{PART V: EUROPE AND NORTH AMERICA}

One of the reasons for being sceptical of generalised claims about globalisation having created a global market in which individual countries no longer matter, is that much of the supposedly 'global' activities of multinational corporations and international financial markets is actually within and between Europe and North America. In both cases, institutional developments have created new regional structures - the North American Free Trade Area (NAFTA), and the European Union (EU). The rhetoric within the EU has been explicit about productivity and competitiveness. In Chapter 14, Joseph Plasmans considers relative productivity within Europe and North America within the context of globalisation, and concludes that local and regional factors are still of great importance in determining relative productivity levels and growth. The conscious effort to create a single European market, with a single currency, is analysed by Philip Arestis and Malcolm Sawyer in Chapter $15 .{ }^{4}$ They stress that this has not been simply a technical exercise, nor a politically neutral one:

The establishment of the euro and the European Monetary Union has been undertaken within a specific institutional and policy framework. The institutional framework gives prominence in policy formulation to an undemocratic and unaccountable European Central Bank. It is a policy framework that emphasises the control of inflation over the reduction of unemployment, although it provides a weak instrument (monetary policy) for the control of inflation and generates macroeconomic policies. The latter tend to increase rather than diminish the level and disparity of unemployment. Economic performance with the euro has been disappointing, and the eurozone is facing very considerable pressures, which put its future in doubt.

The equivalent processes within North America are analysed by Jim Stanford in Chapter 16 in his discussion of NAFTA, where he argues that:

The relatively simple task of eliminating tariffs on intra-NAFTA merchandise trade was a modest portion of the overall NAFTA package. More important was the NAFTA's attempt to establish a continent-wide regime of deregulated, market-oriented economic development. Indeed, the Mexican government's primary interest in the NAFTA may have been precisely to commit itself publicly and permanently to a broadly neoliberal development strategy, thus winning the confidence and approval of both international investors and domestic wealth-holders. The NAFTA had a significant impact on trade and direct investment flows within North America, but the overall impact of NAFTA on aggregate economic variables (such as investment, growth, productivity and incomes) was disappointing, including for Mexico (which was expected by economists to benefit dramatically from its integration within the continental market). The prospects of expanding NAFTA (to include other countries in the Western Hemisphere) or deepening it (to address topics such as monetary integration, border efficiency, or migration) were quickly dashed. Meanwhile, the broader relative decline of the US economy (most dramatically visible in the financial crisis and recession of 2009) imposed spillover consequences on its NAFTA partners, and on the long-run vitality of the continental market generally. Without a substantial revitalization of both North American economic leadership, and initiatives to further intensify and deepen economic links between the three trading partners, NAFTA's long-run economic and political importance was fading.

In Chapter 17, Charles Craypo and Frank Wilkinson analyse the way in which the US economy relates to the global, in particular through exporting jobs via FDI, and importing labour into the US. ${ }^{5}$ Such an analysis is not common, which is surprising given how common and important are the processes being analysed - both to the economy in 
question, and to the citizens of that country, as well as for the citizens of other countries. This is undoubtedly a weakness of mainstream economics, that it does not even ask the right questions, let alone attempt to answer them. Frank Wilkinson's work, on the other hand, is based on the idea of productive systems:

Where neoclassical theory reifies the market and loosens it from its institutional moorings in civil society, the legal system and the organizations of the state, the productive systems approach sees these institutions as playing a central role in the constitution and development of productive forces. Systems of production exist at a number of levels: the workplace; the enterprise or firm; the industrial sector or inter-firm network; nation states; and transnational trading blocs. (Rubery et al., 2002, p. 2)

Craypo and Wilkinson detail and analyse the way in which US corporations make use of immigrant labour in the US, while at the same time relocating production from the US to other countries:

Deregulated markets, short-term corporate performance objectives and overriding shareholder and executive claims on resources now dominate the US productive system. These, together with the increasing globalisation of this system, encourage corporations to cut pay and worsen conditions of work - moves that workers are increasingly powerless to resist. When dominant firms drive down labour costs in this way, others are forced to follow suit or risk operating at considerable disadvantage. This builds on a long historical tradition of wage cost competition based on cutting the pay of existing workforces, recruiting other workers who will work for less, or by simply relocating production to more employer-friendly sites. Within the global productive system, US employers increasingly resort to importing low-wage labour and exporting production processes to low-wage countries. Immigrant labour and emigrant jobs have thus become the hallmark of US labour relations and production strategies.

\section{PART VI: GOVERNANCE}

In Chapter 18, Richard Woodward argues that globalisation points to aspects of both continuity and change in world politics. Similarly, in Chapter 19, Mathias KoenigArchibugi reviews the substantial body of research:

which shows that the performance of governance functions is not limited to the actions of governments exercising sovereign powers over their jurisdictions, but occurs also at supranational and transnational levels. Governance - understood as the establishment and operation of rule systems facilitating the coordination and cooperation of social actors - is conceptually distinct from government - understood as an organisation in charge of administering and enforcing those rules (Young, 1999). The literature discussed in this chapter (originating mostly from political scientists and international relations scholars) maintains that governance is not coextensive with government, and that government should not be seen as a necessary condition of governance. More specifically, it shows that the absence of a world government does not mean that governance is impossible beyond the level of individual states. Global issues such as ozone depletion, the spread of financial crises and the prohibition of certain kinds of weapons are managed by governance structures that do not conform to the hierarchical model of rule-setting and enforcement that is typical of states. The combination of these structures can be said to form a system of global governance.

The key question, of the relationship between globalisation and national economic policy, is then confronted by Simon Lee in his analysis in Chapter 20 of the UK's Labour 
governments of 1997-2010 and its 'third way' - often presented as a response to the constraints of globalisation:

The third way did not reconcile UK domestic economic policy choices with globalisation in a manner that has been able to insulate domestic modernisation from the consequences of increasing volatility and contagion in global financial markets. Following the global financial crisis, during 2009 the UK experienced a fall in GDP of 4.8 per cent, a bigger fall than any year of the Great Depression and the UK's biggest contraction since 1921 (NIESR, 2010: 1). The demise of the political economy of the third way demonstrated that long-term stability in monetary and fiscal policy cannot be guaranteed in a world of liberalised financial markets and volatile short-term capital flows, without effective regulation (United Nations, 2009). Under the political economy of the third way, the sources of imprudence, debt, risk and instability emanated from the private sector and liberalised markets overseas rather than solely from the public sector. The provision of an initially prudent (and latterly imprudent) framework for national macroeconomic policy was not sufficient to guarantee economic stability in the face of a 'risk-based' approach to the governance of financial markets, which empowered speculation and irresponsible risk-taking, at the expense of the taxpayer and manufacturing industry (Lee, 2009).

Tackling these underlying issues will require not just specific policy reforms, such as the introduction of a Tobin tax, ${ }^{6}$ but also the reform of the current international economic institutions.

\section{PART VII: INTERNATIONAL ECONOMIC INSTITUTIONS}

The penultimate part looks at the existing international economic institutions, with Scott Sinclair in Chapter 21 considering the World Trade Organization and its General Agreement on Trade in Services (GATS), which is exerting constant pressure on national governments to open services to foreign commercial providers. The role of the International Monetary Fund and of the World Bank are then discussed by John Toye in Chapter 22. ${ }^{7}$ Toye considers the pressures that have arisen given the criticisms of these institutions following their damaging roles in the Asian financial crisis. ${ }^{8}$

Mića Panić then analyses in Chapter 23 the global economic institutions and considers how best they might be reformed in response both to criticisms that they have failed, and more generally to meet the challenges ahead:

Given the extent of global economic interdependence at the beginning of the twenty-first century, it is increasingly apparent that the world needs urgently a new international institutional framework capable of helping individual countries solve their most pressing economic problems under these conditions. The objective of achieving global public goods through improvements in national economic security and social well-being is as relevant now as it was in the 1940s. However, without the spirit of 'Bretton Woods' - the absence of which is equally obvious at present - it would be virtually impossible to convene another 'Bretton Woods' Conference, let alone to agree on a common course of action and implement it. Much more likely, the realities of interdependence may force an increasing number of countries to organise regional 'Bretton Woods' systems or, following the example of Western Europe, create regional economic and monetary unions.

Globally, however, the most that one can hope for at present is an improvement in the work of the existing institutions along at least some of the lines suggested in this chapter. Unfortunately, the attitude and actions of the world's largest economies in particular, especially since the 1980s, make even the objective of such modest improvements look positively utopian. 


\section{PART VIII: POLICY IMPLICATIONS AND RESPONSES}

The chapter by Mića Panić concludes that the policies that are necessary in the face of global developments appear to have little chance of being implemented at present because of the political opposition from those who consider the current arrangement beneficial to their own economic interests. In Chapter 24, Ha-Joon Chang examines in detail the policy pronouncements from the world economic institutions, the leading industrialised countries who in any case call the shots within those institutions, and the academic economists and other experts within those countries. ${ }^{9}$ The developing countries are, of course, being told that they must follow the free-market prescriptions espoused by the leading industrialised economies. It could, of course, be questioned just how far the leading industrialised economies themselves practise what they preach. But more to the point is to consider what they practised when they were at the same stage of development as the developing countries are today. And here there is absolutely no doubt. Today's rich countries grew rich behind protective barriers and domestic intervention. Those who gain a competitive advantage through such policies are, of course, the first to propose - or demand, if they have the power - free trade. This, Chang argues, is what we are witnessing today. The leading economies, which have manoeuvred themselves into a position of being able to do well in a straight commercial competition with the less developed economies, are now demanding precisely that - the sort of commercial competition in which the rich will become richer, and in which the poorer countries whose industries and firms may not be able to survive such competition will see those industries and firms go to the wall. This will leave those economies no alternative but to import goods from the advanced economies instead - or else invite the multinational corporations from those economies into their countries, to produce domestically.

In Chapter 25, Colin Hines makes the case for rejecting such demands - along with the whole global free-market logic - and instead campaign for an equitable international economic system, along with a proper appreciation of what can be done locally:

To return a sense of hope for the future and economic security for the majority, all governments need urgently to consider embracing a 'jobs in every community' programme. There are two localised and secure labour-intensive sources for this. The first is employment in a range of social services, especially the new growth area of looking after the elderly. The second is decentralised infrastructure projects focusing on a decades-long, multi-skilled programme of energy refits of all nations' millions of dwellings, a shift to localised renewable energy and food production, and the building of local transport and flood defence systems.

In Chapter 26, George DeMartino also challenges the current drive towards a global free market - what he describes as global neo-liberalism - but focuses on the international trading system and how it might best be reformed. By global neo-liberalism he means the policy regime created during the last quarter of the twentieth century in which 'largely unregulated market forces ... override the state in directing international trade and investment flows'; this therefore includes "free" trade, the liberalisation of international financial markets, the global protection of property rights, and so forth'. DeMartino argues that the resulting system is unstable and unsustainable, and that governments will be forced to intervene: the important question is 'what will come next, after the current experiment with free trade has been abandoned?' 
DeMartino considers the various alternatives, including the labour standards arguments that are surveyed in Chapters 11-13. From this he argues for a new policy that would create incentives for such standards to be adopted by all trading nations, with good standards rewarded by the tariff structure and poor standards penalised. He deals with the various objections that have been raised to such standard-setting, and recognises also that such measures would only tackle one part of the system that at present is generating such inequalities and instability globally. The other areas in which action is needed are discussed by several of the other authors in the current volume: tackling the international debt crisis (Dymski), dealing with inequality through domestic policy (Palma), encouraging transnational corporations to operate in ways that would provide economic benefit to those areas in which they operate (Ietto-Gillies, Epstein, Braunstein), setting labour standards nationally and internationally (Brosnan, Heintz), reforming NAFTA (Stanford), the European single currency system (Arestis and Sawyer), the international economic institutions (Sinclair, Toye, Panić), reasserting the legitimacy of government (Lee), allowing developing economies to pursue the sort of industrial policies that proved successful for the currently leading countries (Chang) and encouraging local and regional economic development (Hines). For DeMartino, his proposal for reforming the international trading system - to encourage a ratcheting up of standards in place of the sort of social dumping that can lock all into a downward spiral - would be a supportive contribution to such an alternative agenda.

The 2007-08 international financial crisis and the global recession of 2009, which saw the first decline in global national income since the 1930s, is analysed by Photis Lysandrou in Chapter 27. Lysandrou pinpoints a key factor that has been generally overlooked by other accounts of the causes of the credit crunch, namely the huge increase in inequality, both within and between countries. This process created a large number of high net worth individuals who drove the demand for new financial instruments in which to invest and with which to speculate. To create a new era of sustainable development will require these gross inequalities to be tackled and overcome.

In the concluding chapter, Chapter 28, Geoff Hodgson reflects on what lessons have been learned by the fact that the economics profession appeared to have done such a poor job over the past 30 years in analysing and describing how the economy functions, and in advising on how economies should be regulated and governed to secure sustainable development. That failure of mainstream neoclassical economics needs to be recognised and tackled.

\section{CONCLUSION}

One of the most important conclusions that emerges clearly from a number of the authors is that it is wrong to consider 'globalisation' as representing some natural or technical development that can be then judged as either welcome or otherwise, and reformed accordingly. The facts that international capital markets have been given a free leash to move into unregulated speculation, that the international institutions have been imposing pro-Western policies on the rest of the world and that multinational corporations have been given increasingly free rein, have been the result of policy design and have been pursued by Western governments and the financial and other corporations involved. At 
each stage, a range of other options has been available for designing and constructing the international trading, financial and productive systems. Indeed:

At this juncture, the overriding virtue of the productive systems approach is to re-emphasize the diversity of institutional forms which are present in capitalist systems and the potential solutions to the problem of societal cooperation to coexist. A systems approach cautions against the assumption that changes in national and global trading regimes can in any way be separated from what is happening at the level of the regulatory framework. An emphasis on 'spontaneous' convergence between systems can only obscure the important policy choices to be made in national and global governance. (Rubery et al., 2002, p.9)

That is, there is an alternative. History has not come to an end; it is still being made. The question is, in whose interests? There is no doubt that over the past 30 years or so, policy has been driven by the interests of the international financial system and the transnational corporations. This has at times been recognised by those responsible, even as they acted, with talk therefore of balancing these imbalances through the introduction of the 'social chapter' to the EU's Maastricht Treaty on monetary union, and environmental and labour standards clauses in NAFTA. But the main drive has remained a free-market one, despite the inequalities and instabilities that this inevitably generates.

Why has policy taken such a turn, following the much more successful 25 years up to the mid-1970s? In part the answer is, of course, that there have been powerful interests that have benefited, and in the struggle between economic interests, these have gained the upper hand. It may also be partly due, though, to the inability of mainstream economics to even recognise the above factors, let alone analyse them and propose alternative policies. In the world of textbook neoclassical economics, the free-market outcome will maximise economic welfare. It may be acknowledged that there will be losers as well as winners when markets are deregulated, but, the theory goes, the winners could compensate the losers, so all would become better off. And in theory, perhaps they could.

In practice, however, the world works rather differently. The textbook model may provide a useful analytical tool, but it is not a description of reality, and the attempts to change reality to fit the model are misguided and destructive of the sort of social, political and economic institutions that historically have actually created economic growth and social progress. This needs to be recognised for appropriate policy to be generated and pursued. Of course, there would still be powerful interests that would prefer the current free-for-all. But at least such behaviour could be seen for what it is - an attempt by those with economic power to enjoy more of the spoils.

The alternative to mainstream, neoclassical economics has, of course, continued to analyse the world as it is, and the large literature on alternative economic analysis and policy discussion can only be touched on by the various authors below. ${ }^{10}$ Baker et al. (1998) set out a comprehensive approach to progressive economic policy in the era of globalisation. ${ }^{11}$ And many of the chapters in this volume themselves build upon large literatures. Howells (Chapter 5) discusses the importance of innovation systems, and the policy implications are set out elsewhere (for example, Howells and Michie, 1997; Archibugi, et al., 1999). Ietto-Gillies (Chapter 8) has set out in detail the role of transnational corporations in the global economy (see, for example, Ietto-Gillies, 2001, 2002). And in particular, Chapters 24-26 on policy implications and responses all draw on work that was developed more fully by the authors' own books: Chang (2002), Hines (2002) and DeMartino (2000). 
A 1999 collection on Global Instability - with many of the same authors as in this collection - was introduced in the following terms, which applies just as much today, and to the chapters contained in the current volume:

The problems witnessed in today's global economy are not just technical, economic ones. They are also political. Devising new structures of World Economic Governance requires, as a starting point, that this be recognised. This means that to be successful, any alternative needs to not only spell out appropriate policy and institutional developments, it also needs to win sufficient political support to force through the necessary change of course.

In this context, ideological issues also play a role. It is thus necessary to expose the current complacent orthodoxy in mainstream economics, and challenge the fatalistic belief that the new globalised economy rules out any change of course. As many of the chapters that follow demonstrate, the fact that the economy is becoming increasingly internationalised does not dictate the form that this process is taking. The free market, laissez-faire agenda is one being pursued by those who benefit from such a deregulated, winner-take-all environment. It is not the only choice. And for the majority of the world's population, it is an inappropriate one. (Michie, 1999, p. 6)

In the face of the 2008 international financial crisis, UK Prime Minister Gordon Brown acknowledged 'the collapse of a failed laissez-faire dogma'. The University of Oxford held an online debate on whether the crisis sounded the death knell of laissez-faire capitalism - with 54 per cent voting in favour of the motion (University of Oxford, 2008). In that debate I argued that coordinated international action, including nationalisation, fiscal deficits and regulation, had indeed replaced the previous laissez-faire approach, but asked whether laissez-faire capitalism would seek to make a comeback once the mess it created had been cleared up. The answer, I argued, is that if we let it, yes it will; that there are vast private fortunes to be had; that we must ensure that the lessons learned from the global banking crisis are not lost; that we need a sustainable future in economic as well as environmental terms; and that laissez-faire capitalism would endanger both - unleashing another era of unsustainable speculative activity, while ignoring the environmental consequences:

Regulation can ensure environmental effects are factored into decision-making. This need not be a cost - on the contrary, it can act as a spur for industry to invest in green growth, knowing that the alternatives will be increasingly outlawed. That way, directors can justify long-term investments in green technologies to their shareholders - because regulation will make this the only way of enjoying sustainable profits in the future. Otherwise, their fiduciary duty is to make short-term financial returns by speculating on the markets along with everyone else. It is a question of what sort of system we design and maintain - one of laissez-faire capitalism, where short-term financial returns are maximised, or one where activities are regulated to take account of the environmental and economic costs that society would otherwise have to bear. (Michie, 2008)

The alternative system for the international economy - where activities are regulated to take account of the environmental and economic costs that society would otherwise have to bear - is set out and argued in detail in Michie (2017 and 2018), where I argue for a 'Global Green New Deal' to replace the era of capitalism unleashed that led to the 2007-08 international financial crisis and the resulting global recession of 2009, and the subsequent decade that was lost to austerity. That alternative, I argue, needs to tackle inequality and tax evasion, as well as climate change, and needs a more diversified corporate structure, including more member-owned companies (mutuals, co-operatives, and 
co-owned businesses) - as described and advocated by the leading international experts brought together by Michie, Blasi and Borzaga (2017). This would be globalisation for a purpose.

\section{NOTES}

1. The topic of globalisation - and the accompanying literature - is also critically analysed and discussed in the University of Oxford's online course on Globalisation, from which the opening paragraphs above are taken (see www.conted.ox.ac.uk), as well as in the University of Oxford's iTunes U podcast series by Michie and Yueh (see http://itunes.ox.ac.uk/).

2. Because Andrew Glyn passed away before this updated edition was prepared, this chapter is reprinted from the previous edition.

3. Written in 1847 (published 1848) by Marx and Engels, The Communist Manifesto.

4. There is, of course, a huge literature on the development of the EU and single currency; see, for example, Healey (1995), Amin and Tomaney (1995) and Moss and Michie (1998).

5. Chuck Craypo passed away before this updated edition was prepared, so this chapter is reprinted from the previous edition.

6. On which, see, for example, Arestis and Sawyer (1999).

7. On the World Bank, see also Wade (2002).

8. On which, see Stiglitz (2002).

9. Ha-Joon Chang was unable to update his chapter for this edition; however, his chapter summarised his own book, which continues to represent a substantive contribution to the literature (Chang, 2002), so this chapter is reprinted from the previous edition.

10. For a critique of the mainstream neoclassical approach, see Kitson and Michie (2000), Chapter 1; this book also includes an analysis of globalisation (Chapter 2) and trade theory (Chapters 3 and 4).

11. The literature on globalisation is also surveyed from the various disciplinary approaches by Power (2001) for economics; Lukens-Bull (2001), human geography; Williams (2001), management and business; Lee (2001), politics; Hills (2001), sociology; Hines (2001), 'critiques and alternatives'; and Archibugi (2001), innovation studies.

\section{REFERENCES}

Amin, A. and J. Tomaney (eds) (1995), Behind the Myth of European Union: Prospects for Cohesion, London: Routledge.

Archibugi, D. (2001), 'Globalization of technology', in J. Michie (ed.), Reader's Guide to the Social Sciences, London: Fitzroy Dearborn/Routledge.

Archibugi, D., J. Howells and J. Michie (eds) (1999), Innovation Policy in a Global Economy, Cambridge: Cambridge University Press.

Arestis, P. and M. Sawyer (1999), 'What role for the Tobin tax in world economic governance?', in J. Michie and J. Grieve Smith (eds), Global Instability: The Political Economy of World Economic Governance, London: Routledge.

Baker, D., G. Epstein and R. Pollin (eds) (1998), Globalization and Progressive Economic Policy, Cambridge: Cambridge University Press.

Chang, H.-J. (2002), Kicking Away the Ladder: Development Strategy in Historical Perspective, London: Anthem Press.

Costello, N., J. Michie and S. Milne (1989), Beyond the Casino Economy, London: Verso.

DeMartino, G.F. (2000), Global Economy, Global Justice: Theoretical Objections and Policy Alternatives to Neoliberalism, London: Routledge.

Healey, N.M. (ed.) (1995), The Economics of the New Europe, London: Routledge.

Hills, M. (2001), 'Globalization, sociology', in J. Michie (ed.), Reader's Guide to the Social Sciences, London: Fitzroy Dearborn/Routledge.

Hines, C. (2001), 'Globalization, critiques and alternatives', in J. Michie (ed.), Reader's Guide to the Social Sciences, London: Fitzroy Dearborn/Routledge.

Hines, C. (2002), Localization: A Global Manifesto, London: Earthscan.

Hirst, P. and G. Thompson (1996), Globalization in Question, Cambridge: Polity Press. 


\section{The handbook of globalisation}

Howells, J. and J. Michie (eds) (1997), Technology, Innovation and Competitiveness, Cheltenham, UK and Lyme, NH, USA: Edward Elgar.

Ietto-Gillies, G. (2001), Transnational Corporations: Fragmentation amidst Integration, London: Routledge.

Ietto-Gillies, G. (2002), 'How internationalised are EU transnationals?', Journal of Interdisciplinary Economics, 13(1-3), 13-49.

Kitson, M. and J. Michie (2000), The Political Economy of Competitiveness: Essays on Employment, Public Policy and Corporate Performance, London: Routledge.

Lee, S. (2001), 'Globalization, politics', in J. Michie (ed.), Reader's Guide to the Social Sciences, London: Fitzroy Dearborn/Routledge.

Lee, S. (2009), Boom to Bust: The Politics and Legacy of Gordon Brown, Oxford: Oneworld.

Lukens-Bull, R. (2001), 'Globalization, human geography', in J. Michie (ed.), Reader's Guide to the Social Sciences, London: Fitzroy Dearborn/Routledge.

Michie, J. (1995), 'Introduction', in J. Michie and J. Grieve Smith (eds), Managing the Global Economy, Oxford: Oxford University Press.

Michie, J. (1996), 'Creative destruction or regressive stagnation?', International Review of Applied Economics, 10(1), 121-6.

Michie, J. (1999), 'Introduction', in J. Michie and J. Grieve Smith (eds), Global Instability: The Political Economy of World Economic Governance, London: Routledge.

Michie, J. (2008), 'Closing Statement', in University of Oxford (2008).

Michie, J. (2017), An Advanced Introduction to Globalisation, Cheltenham, UK and Northampton, MA, USA: Edward Elgar.

Michie, J. (ed.) (2017), Globalisation and Democracy, 3 volumes, Cheltenham, UK and Northampton, MA, USA: Edward Elgar.

Michie, J. (2018), 'Forms of globalisation: from "capitalism unleashed" to a global green new deal', European Journal of Economics and Economic Policies: Intervention, 15(2), 163-73.

Michie, J., J.R. Blasi and C. Borzaga (eds) (2017), The Oxford Handbook of Mutual, Co-operative, and Co-owned Business, Oxford: Oxford University Press.

Moss, B.H. and J. Michie (eds) (1998), The Single European Currency in National Perspective: A Community in Crisis?, London: MacMillan.

NIESR (2010), 'Biggest contraction since 1921', NIESR Monthly Estimates of GDP, 13 January.

Power, D. (2001), 'Globalization, economic', in J. Michie (ed.), Reader's Guide to the Social Sciences, London: Fitzroy Dearborn/Routledge.

Rubery, J., B. Burchell, S. Deakin and J. Michie (2002), 'Productive systems: introduction and overview', in B. Burchell, S. Deakin, J. Michie and J. Rubery (eds), Systems of Production: Markets, Organisations and Performance, London: Routledge.

Stiglitz, J. (2002), Globalization and Its Discontents, London: Penguin.

United Nations (2009), Report of the Commission of Experts of the President of the United Nations General Assembly on Reforms of the International Monetary and Financial System, New York: United Nations.

University of Oxford (2008), 'The current financial crisis sounds the death knell for laissez-faire capitalism', online debate, www.ox.ac.uk/oxford_debates/past_debates/michaelmas_2008_lais sezfaire_capitalism/index. html; accessed 4 October 2010.

Wade, R.H. (2002), 'US hegemony and the World Bank: the fight over people and ideas', Review of International Political Economy, 9(2), 201-29.

Williams, A. (2001), 'Globalization, management and business', in J. Michie (ed.), Reader's Guide to the Social Sciences, London: Fitzroy Dearborn/Routledge.

Young, O.R. (1999), Governance in World Affairs, Ithaca, NY and London: Cornell University Press. 